\title{
KÖZPONTI-HELYI KÖLTSÉGVETÉSI KAPCSOLATOK Elvek és módszerek
}

\author{
Péteri Gábor (szerk.) Budapest, 1994. 204 o. (k. n.)
}

Az 1990. évi helyi önkormányzatokról szóló törvény elfogadása óta a szerkesztó írásaiból és általa szerkesztett tanulmányokból, illetve szakmai anyagokból figyelemre méltó és a szakmai közvéleményt is motiváló munkákat olvashattunk.

A központi-helyi költségvetési kapcsolatok címet viselö tanulmánykötet különösen fontos napjainkban, amikor folyamatban van az államháztartás reformja, mely módosítja a központi költségvetés és az önkormányzatok költségvetésének kapcsolatrendszerét és az államháztartáson belüli arányokat egyaránt.

Mindezekre szükség van, hiszen a jelenlegi arányok nem tükrözik a fennálló munkamegosztást és még kevésbé felelnek meg az önkormányzati törvényben megfogalmazott feladatmegosztásból következö arányoknak. Ebből adódott, hogy bár növekedett az önkormányzati szféra részaránya az államháztartási mérlegen belül, de ez a növekedés nem tartott lépést az önkormányzatok feladatainak kiterjesztésével.

A kötet első két tanulmánya - a szerkesztỏ Péteri Gábor és Agg Zoltán írása - a települési és a körzeti feladatok finanszírozási problémáival foglalkozik és elemzi az önkormányzatok által fenntartott, illetve fenntartandó intézményi kör pénzügyi kérdéseit. Mivel a közreadott tanulmányok az Országgyủlés Önkormányzati és Rendészeti Bizottsága számára készültek, így tekinthetjük a műhely- munka és a törvényhozás szélesebb nyilvánossága jelének is a könyvet.

Figyelemre méltó a szerkesztó azon megállapítása, mely szerint „A modern közszolgáltatási rendszerben a központi és a helyi feladatok tartalmi elkülönítése a gyakorlatban nem oldható meg. A funkciók merev szétválasztásából következö önkormányzati teljes körủ feladatfinanszirozás nem múködöképes. A helyi szolgáltatások esetében a nagyobb méretekkel csökkenő fajlagos költségek szabálya nem mindig érvényes. Egy kevésbé tagolt települési önkormányzati rendszer nem feltétlenül lenne hatékonyabb. A decentralizáció mellett egyébkent is elsődlegesen politikai és nem közgazdasági érvek szólnak." (29. o.). Egyetérthetünk ezzel a megállapitással, hiszen a finanszírozás mai rendszere nem veszi figyelembe a méretgazdaságosság és a költséggazdálkodás kritériumait, ugyanakkor azt is tudjuk, hogy az önkormányzati rendszer széttagolt, a feladatok megosztásánál és az intézményrendszer müködtetésénél sem érvényesülnek a közgazdasági, gazdaságossági kritériumok.

Agg Zoltán írásában kiemeli, hogy „A feladatok megosztásánál ugyanis a fö törésvonal nem a megye és a települések között, hanem a helyi önkormányzatok és az állam között - pénzben, hatalomban és képviseletben - húzódik." (43. o.). Ezeknek a problémáknak a szakmai elemzésével részletesen is foglalkozik a szerző ezen 
tanulmánya mellett a Pálné Kovács Ilonával közösen szerkesztett kötet, mely „A rendszerváltás és a megyék" címınel jelent ineg (Comitatus, Veszprém, 1994, 239 o.).

Ugyancsak a kötet szerkesztőjének irása foglalkozik ,A helyi központi pénzügyi kapcsolatok" címmel a helyi feladatok finanszírozásának inkonzisztens rendszerével, a kiegyenlítő mechanizmusok hiányával és a támogatások elosztási rendszerének kritikájával. A tanulmányokban és a mellékletekben közölt táblázatok szemléletes összefoglalásai az elméleti következtetéseknek, a közölt adatok egzakt módon is tükrözik a finanszírozás dilemmáit, hazai gondjainkat, a nemzetközi összehasonlítást is lehetővé téve az olvasó számára.

Az önkormányzati gazdálkodást elemzö írások az elmúlt időszakban fóként a költségvetés kérdéseivel foglalkoztak és kevesebb figyelmet szentelt a szakma és a politika az önkormányzati vagyongazdálkodás kérdéseinek. Eire hivta fel a figyelmet több írásában Pitti Zoltán, akinek a kötetben ,Gondolatok az önkormányzati gazdálkodásról, a vagyonhasznosítás kezdeti eredményeiről, a szabályozórendszer korszerúsítésének lehetséges és kívánatos irányairól" címmel olvashatjuk tanulmányát. A mellékletben közölt 12 táblázat és a tanulmányban közzétett adatok gazdag információs bázist biztosítanak a szerzô elemzéseihez és következtetéseihez, illetve a témával foglalkozó kutatóknak és gyakorlati szakembereknek egyaránt. A szerzó kiemeli, hogy az önkormányzati vagyon létrejöttével és a vagyon felértékelödésével az önkormányzati gazdálkodás (vele együtt a vállalkozási tevékenység) fontos elágazási ponthoz érkezett, vagyis az egyik irány lehet annak kimondása, hogy az elkülönült vagyon idegen test a közigazgatásban és az önkormányzati szférában, ezért a kialakult helyzetet átmenetinek kell tekinteni - vagyis mielőbb meg kell kezdeni az önkormányzati tulajdon magánosítását (vagy éppen államosítását), a másik irány annak felisımerése, hogy az önkormányzatok olyan vagyontömeghez jutottak, aminek szakszerủ és eredményes múködtetése meghaladja mai felkészültségüket, ebböl következóen a legfontosabb feladat a megváltozott követelményekhez való igazodás, vagyis az önkormányzati vagyongazdálkodás jogi, gazdasági, szervezeti és személyi feltételeinek megteremtése. (110-111.o.).

A tanulinány összefoglalásaként a szerző felsorolja a legsürgetőbb vagyongazdálkodási tennivalókat ahhoz, hogy az önkormảnyzatok passziv vagyonkezelöböl aktiv gazdálkodóvá váljanak, mely feladatrendszernek természetesen része az önkormányzatok szervezódésének adózási szempontból történỏ végiggondolása, nivel az önkormányzatoknak - ,...mint végső felhasználóknak - nagyjából vảltozatlan költségvetésböl kell elszenvedniük az adózással járó többletterheket. $\mathrm{Be}$ kellene végre látni, ha a környezet piacosodik, akkor annak hatása alól a helyi közösségek sem vonhatják ki magukat." (114. o.).

A kötetben két tanulmányt olvashatunk Várfalvi Istvántól, a körzeti jellegü szolgáltatások finanszírozása és a cél- és címzett támogatási rendszer megújítási lehetöségei témakörben.

A mélyebb ellentmondảs mögött „...valójában (nagyon helyesen) a település (önkormányzat) centrikus normativ 
pénzügyi szabályozás és a több települést is ellátó közszolgáltatás (föleg, de nemcsak intézményi) struktúrák közti allokációs feszültség, s annak mechanizmuskonform feloldási igénye húzódik." (168. o.). Különösen figyelemre méltó a szerzö megközelítési módja, mivel igyekezett a jelenlegi makroszintú pénzügyi kereteken belül maradva elsősorban ,átcsoportosításokkal" megteremteni a szükséges forrásokat, bár esetenként elkerülhetetlennek tünt így is a kisebb összegú többletforrás bevonása. Az összefoglaló részben (180. o.) a cél- és címzett támogatás rendszerének megújítási lehetőségeinél a szerző külön kitér arra, hogy az ,eddiginél nagyobb központi önmérsékletre van szükség", mivel fontos, hogy az állam csak a legszükségesebb mértékben avatkozzon be - a befolyásolás eszközével - a települések mindennapi életébe. Ehhez szükséges, az Országgyülés és a középszint (nemcsak a megyei önkormányzat közötti felelösségi és jogi viszonyok továbbgondolása) és különösen a területfejlesztési feladatok új típusú szabályozása.

Zárótanulmányként Glen Wright „Tanulmány a központi és az önkormányzati funkciók megosztásáról" címủ írását olvashatjuk. A tanulmány elméleti összefoglalást nyújt - a hatáskör alapján definiálható modellekröl, igy bemutatja a relativ autonómia, az ügynökségi és kölcsönhatásos modelleket és kiemeli azt a tendenciát, mely az álcentralizáció és az önkormányzatok nagyobb fokú autonómiája irányába mutat (Nagy-Britannia kivételével). A szerző a kötelezö és önkéntes feladatoknak és szolgáltatásoknak a központi költségvetés és az önkormányzatok közötti megosztását vizsgálta nemzetközi összehasonlításban. Ezen keresztül bemutatta, hogy az Európában az önkormányzatoknál meghatározott számos szolgáltatási funkció Magyarországon ma még nem került kijelölésre.

A tanulmánykötet érdeme amellett, hogy a törvényhozás, illetve a bizottsági döntéshozatal szakmai támogatását segítette, különösen az, hogy további kutatásra és szakmai vitákra ösztönzi az önkormányzatokkal, illetve a költségvetéssel foglalkozó elméleti és gyakorlati szakembereket, melyhez megfelelő információt is nyújt.

László Mária 